\title{
Ocena wpływu właściwości petrofizycznych skał łupkowych na ich efektywność uszczelniania poziomów zbiornikowych i akumulacji złożowych
}

\begin{abstract}
Praca odnosi się do zagadnień oceny formacji łupkowych pod kątem ich efektywności uszczelniania poziomów zbiornikowych węglowodorów. Celem podjętych działań było wypracowanie skutecznych metod analizy i interpretacji formacji uszczelniających, zarówno od strony laboratoryjnych analiz parametrów petrofizycznych, jak i stosowania technik interpretacyjnych i obliczeniowych w skali profili otworów wiertniczych i modeli geologicznych złóż i systemów naftowych. Analizie poddano parametry petrofizyczne dolnopaleozoicznego kompleksu lupkowego basenu bałtyckiego i zdefiniowano reprezentatywny typ (model) skały uszczelniającej, któremu nadano odpowiednie charakterystyki relacji porowatość vs. przepuszczalność i porowatość vs. ciśnienie kapilarne przebicia. Przeprowadzono symulacje systemu naftowego w rejonie anonimowego obiektu złożowego, stosując opracowaną charakterystykę kompleksu uszczelniającego poziom zbiornikowy, oraz oceniano efekty złożowe w postaci parametrów definiujących wielkość akumulacji HC (wysokość kolumny HC, głębokość konturu wody złożowej). Wyniki porównywano z efektami stosowania innych, niezależnych technik interpretacyjnych (danych geofizyki otworowej), potwierdzając skuteczność zastosowanych metod oceny formacji uszczelniających.
\end{abstract}

Słowa kluczowe: skały uszczelniające, migracja węglowodorów, parametry petrofizyczne, akumulacje węglowodorów.

\section{Evaluation of the impact of the petrophysical properties of shale formations on their sealing efficiency for underburden reservoir intervals and hydrocarbon accumulations}

\begin{abstract}
The paper refers to the issues of sealing efficiency of shale formations as rocks covering hydrocarbons reservoir intervals. The aim of the research was to develop effective methods for the analysis and interpretation of the sealing formations, both from the point of view of petrophysical laboratory measurements, as well as the use of techniques of geophysical borehole data interpretation and computations carried out for geological reservoir models and petroleum systems models. The petrophysical parameters of the lower Paleozoic shale sediments of the Baltic basin were analyzed and a representative type (model) of sealing rocks was defined. Appropriate characteristics of the porosity vs. permeability relationship as well as porosity vs. pressure capillary pressure relationship were given to the model. Simulations of the petroleum system were run in the region of an anonymous reservoir object, using the developed characterization of sealing complex to evaluate the reservoir accumulation outcome through such parameters of the reservoir as: HC column height, gas water contact depth. The results were compared with those resulting from other independent techniques of interpretation (well logging data interpretation of water saturation), which confirmed the effectiveness of the methods used for the assessment of the sealing strength of shale formations.
\end{abstract}

Key words: sealing rock, migration of hydrocarbons, petrophysical parameters, accumulations of hydrocarbons.

\section{Wprowadzenie}

Wśród warunków koniecznych powstawania i zachowania złóż węglowodorów, zarówno konwencjonalnych, jak i niekonwencjonalnych, wymienia się:

- odpowiednie cechy skał macierzystych (będących też nie- konwencjonalnymi poziomami zbiornikowymi typu gas shales lub oil shales), takie jak: zawartość substancji organicznej, typ kerogenu, dojrzałość termiczna, jak również ich miąższoośc, 
- głębokość zalegania i historię pogrzebania osadów,

- właściwości petrofizyczne i parametry złożowe - stopień zachowania porowatości oraz ewolucję wykształcenia przestrzeni porowej skał będących poziomami akumulacji węglowodorów (piaskowców, węglanów, łupków, mułowców i innych) w skali czasu geologicznego, rozwój porowatości wtórnej (kerogenowej), właściwości filtracyjne skał, relację pomiędzy porowatością a przepuszczalnością i inne,

- warunki ciśnienia i temperatury panujące w poziomach akumulacji węglowodorów.

Na tym tle nieco niedocenianym i mniej wnikliwie studiowanym kryterium występowania i zasobności złóż ropy naftowej i gazu ziemnego są uwarunkowania i cechy fizyczne skał stanowiących uszczelnienie akumulacji węglowodorów. Dotyczy to wszelkiego rodzaju złóż ropy naftowej i gazu ziemnego, zarówno konwencjonalnych, jak i niekonwencjonalnych. Tematyka oceny formacji uszczelniających jest zagadnieniem rzadko poruszanym w światowej literaturze przedmiotu $[2,6$, 10, 12-14]; w literaturze polskojęzycznej nie ma do tej pory opracowań poświęconych ilościowym ocenom parametrów formacji uszczelniających poziomy zbiornikowe węglowodorów.
Mechanizmy migracji węglowodorów oraz ich akumulacji w pułapkach złożowych mogą być analizowane poprzez zintegrowane wykorzystanie wyników specjalistycznych pomiarów petrofizycznych oraz ich kompleksowej interpretacji, oraz metod dynamicznego modelowania systemów naftowych. Efektywność uszczelnienia poziomu zbiornikowego, przy założeniu odpowiedniego zasilania migrującymi węglowodorami, decydować będzie o możliwości nasycenia pułapek złożowych (obiekt pozytywny/negatywny) lub też - w przypadku pułapek o potwierdzonym nasyceniu HC - o wysokości kolumny węglowodorów (ropy i/lub gazu), jaką jest w stanie utrzymać interwał skał uszczelniających o zadanej miąższości $[3,6,8,10]$. O efektywności uszczelnienia decyduje szereg parametrów: skład mineralogiczny i wykształcenie facjalne skał, przebieg procesów kompakcji determinujących takie cechy formacji geologicznych jak: porowatość, średnice porów, przepuszczalność skał, ciśnienia kapilarne przebicia skał uszczelniających (ang. capillary entry pressure) $\mathrm{i}$ ciśnienia porowe $\mathrm{w}$ poziomie zbiornikowym. Osobną grupę czynników stanowią parametry migrujących mediów złożowych (typ płynu złożowego - ropa/gaz, gęstość, lepkość) [8, 12, 13, 14].

\section{Obiekt badawczy - model syntetyczny z obszaru basenu bałtyckiego}

Prace dotyczące modelowania migracji i analizy warunków uszczelnienia oraz akumulacji węglowodorów prowadzono na syntetycznym zestawie danych, to jest wykorzystywano model geologiczny obiektu strukturalnego z rejonu basenu bałtyckiego o potwierdzonym, lecz nie do końca rozpoznanym charakterze nasycenia węglowodorami (rysunek 1). Dla obiektu tego dysponowano wynikami pomiarów parametrów petrofizycznych i geochemicznych formacji zbiornikowej oraz skał macierzystych, jak również zinterpretowanymi na podstawie danych geofizyki otworowej ciągłymi profilami parametrów formacji geologicznych, takich jak: skład mineralogiczny, porowatość, charakter nasycenia mediami złożowymi. Z kolei w otworach odwierconych na analizowanej strukturze brak było pomiarów właściwości petrofizycznych interwałów uszczelniających poziom zbiornikowy.

W związku z tym wykorzystywano dane petrofizyczne z otworów zlokalizowanych $w$ innym fragmencie basenu bałtyckiego, znajdujących się w znacznym oddaleniu od modelowanego obiektu (kilkadziesiąt kilometrów).
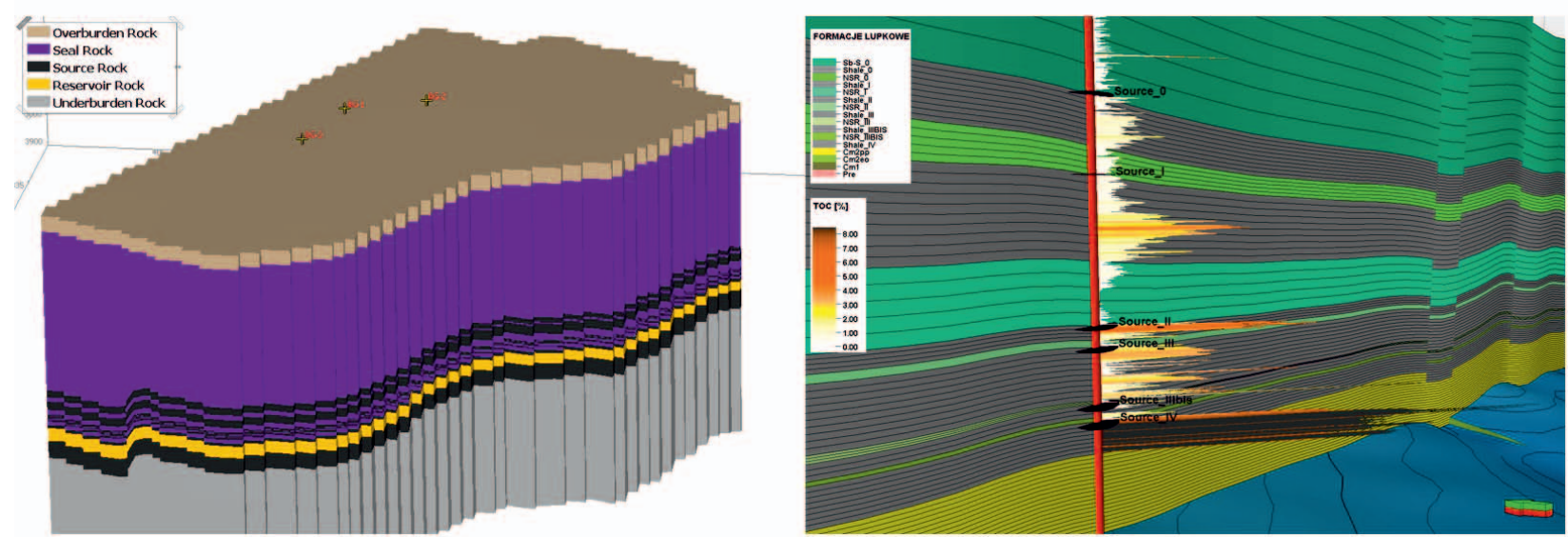

Rys. 1. Szkic modelu geologicznego obszaru badań (po lewej) z wyznaczonymi poziomami macierzystymi (kolor szary), poziomem zbiornikowym (kolor żółty) i kompleksem uszczelniającym (kolor fioletowy); po prawej - przykładowy profil parametru TOC w rejonie badań 


\section{Mechanizmy migracji węglowodorów w basenach sedymentacyjnych w skali czasu geologicznego}

Migracja to proces przemieszczania się wygenerowanych w skałach macierzystych węglowodorów w obrębie i pomiędzy formacjami budującymi baseny sedymentacyjne. Wyróżnia się kilka odmiennych stadiów/wariantów przebiegu procesów migracji węglowodorów $[8,13,14]$ :

- migrację pierwotną - przepływ płynów w skale macierzystej przed rozpoczęciem etapu ekspulsji,

- migrację wtórną - przepływ węglowodorów przez skały przewodzące (ang. carrier) do poziomów zbiornikowych i/lub pułapek złożowych,

- migrację trzeciorzędną/rozproszenie - transport węglowodorów ze skał zbiornikowych lub bezpośrednio z formacji macierzystych do powierzchni,

- remigrację - przemieszczanie się mas węglowodorów pomiędzy poziomami zbiornikowymi lub pułapkami w obrębie jednej formacji zbiornikowej, np. w wyniku przebudowy strukturalnej basenu, powstania nowych dróg migracji (uskoki, szczeliny).

O tym, jakie etapy procesów migracji zachodziły w basenie sedymentacyjnym, decydują szeroko rozumiane uwarunkowania geologii systemów naftowych, w szczególności ewolucja strukturalna i przebieg procesów kompakcji, zmiany reżimu ciśnień porowych oraz warunki termiczne i stopień przeobrażenia materii organicznej. Procesy migracji węglowodorów odbywają się wskutek różnicy ciśnień w basenie sedymentacyjnym i napędzane są przez jeden lub kilka spośród następujących czynników [13, 14]:

- siła wyporu (ang. buoyancy) - kontrast gęstości pomiędzy węglowodorami i wodą,
- kapilarne nasiąkanie (ang. imbibition) - różnice ciśnień kapilarnych pomiędzy warstwami osadów drobno- i gruboziarnistych; wypieranie z przestrzeni porowej skał płynu przez inny płyn,

- kompakcje osadów - ruch wód wyciskanych z osadów ulegających kompakcji,

- potencjał chemiczny - różnice w koncentracji jonów w mediach złożowych prowadzące do procesu dyfuzji.

W analizie zjawisk migracji węglowodorów na kontakcie skała zbiornikowa i skała uszczelniająca największe znaczenie mają wartości ciśnień kapilarnych skał budujących formację uszczelniającą. Po przekroczeniu wartości ciśnienia kapilarnego przebicia skał uszczelniających następuje inwazja węglowodorów w warstwę uszczelniającą (ang. break through) - rysunek $2[8,12,13,14]$.

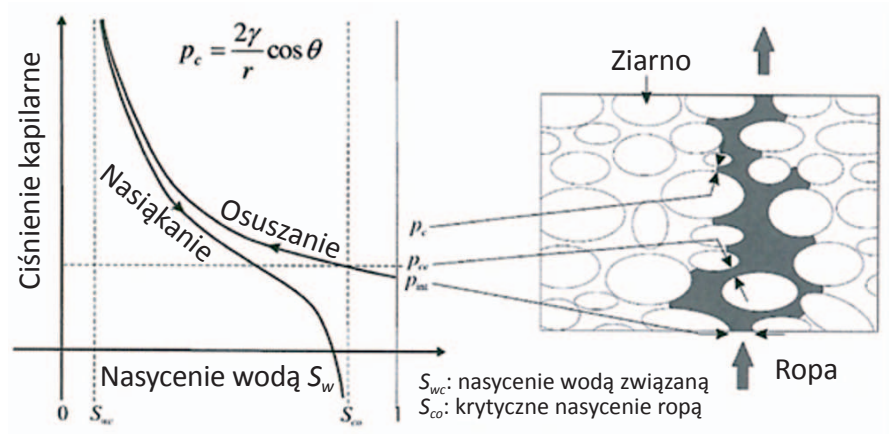

Rys. 2. Zależność ciśnienia kapilarnego od nasycenia wodą złożową (po lewej) i schematyczny szkic inwazji węglowodorów w przestrzeń porową formacji geologicznej $[8,14]$

\section{Właściwości petrofizyczne wpływające na efektywność uszczelnienia}

Spośród parametrów petrofizycznych wpływających na efektywność uszczelnienia, jaką charakteryzują się formacje ekranujące akumulacje węglowodorów, największe znaczenie mają: porowatość otwarta, parametry wykształcenia przestrzeni porowej oraz zwilżalność skał budujących formacje uszczelniające $[1,4,16,18]$ :

1. Porowatość otwarta $-z$ jednej strony wpływ tego parametru jest oczywisty (skały nieporowate są również skałami nieprzepuszczalnymi). $Z$ drugiej zaś, w zależności od rozmiaru porów czy szczelin, skały o niskiej porowatości mogą charakteryzować się znaczną przepuszczalnością. Stosowanie porowatości jako parametru określającego właściwości uszczelniające wymaga wyznaczenia formuły wiążącej obie te wielkości. Może to być krzywa fenomenologiczna powstała na podstawie badań serii pomiarowych dla danej formacji [18]. Będzie to np. krzywa typu: gdzie:

$$
\text { przep }=a \cdot \text { por }^{b}
$$

przep - przepuszczalność efektywna,

por - porowatość otwarta,

$a, b$ - stałe liczbowe.

2. Przez parametry wykształcenia przestrzeni porowej rozumie się rozkład promieni porów w przestrzeni porowej, które powiązane są z ciśnieniami kapilarnymi formułą Washbourne'a [7, 9]:

$$
p_{c}=\frac{2 \gamma \cdot \cos \theta}{r}
$$

gdzie:

$p_{c}$ - ciśnienie kapilarne,

$\gamma$ - współczynnik napięcia międzyfazowego, 
$\theta$ - kąt kontaktu,

$r$ - promień porów.

3. Zwilżalność - określa zachowanie się cieczy przy kontakcie ze skałą. Jej miarą jest kąt kontaktu (występujący w formule Washbourne'a).

\section{Analiza ciśnień przebicia}

Analizę ciśnień kapilarnych, a docelowo ciśnień kapilarnych przebicia wykonuje się przy wykorzystaniu krzywych kumulacyjnych rozkładu promieni porów [17, 20]. Krzywa kumulacyjna wiąże promienie gardzieli porowych z objętością porów, które są napełniane przez wtłaczaną pod ciśnieniem rtęć. Obliczenia wykonuje się, stosując model cylindrów kapilarnych przestrzeni porowej. Na rysunku 3 zamieszczono dwa typowe przebiegi krzywych kumulacyjnych przebadanych skał łupkowych z obszaru basenu bałtyckiego.

Krzywa typu I (kolor czerwony) zachowuje typowy, jednomodalny przebieg. Próbek wykazujących tego typu charakterystykę jest około 30\%. Liczbą 3 oznaczono punkt przegięcia krzywej. Ma on ważne znaczenie fizyczne i jego współrzędna na osi poziomej nazywa się promieniem progowym. Jest to promień porów, przy którym zaczyna się ciągły przepływ płynów złożowych przez skałę. Krzywe tego typu mają wartości promienia progowego rzędu $0,1 \div 0,01 \mu \mathrm{m}$.

Krzywa typu II (kolor niebieski) jest krzywą bimodalną; w jej przebiegu wyróżnia się dwie wartości promieni progowych (oznaczonych cyframi 1 i 2). Większa wartość zawiera się w przedziale $1 \div 0,1 \mu \mathrm{m}$, druga jest mniejsza od $0,01 \mu \mathrm{m}$.

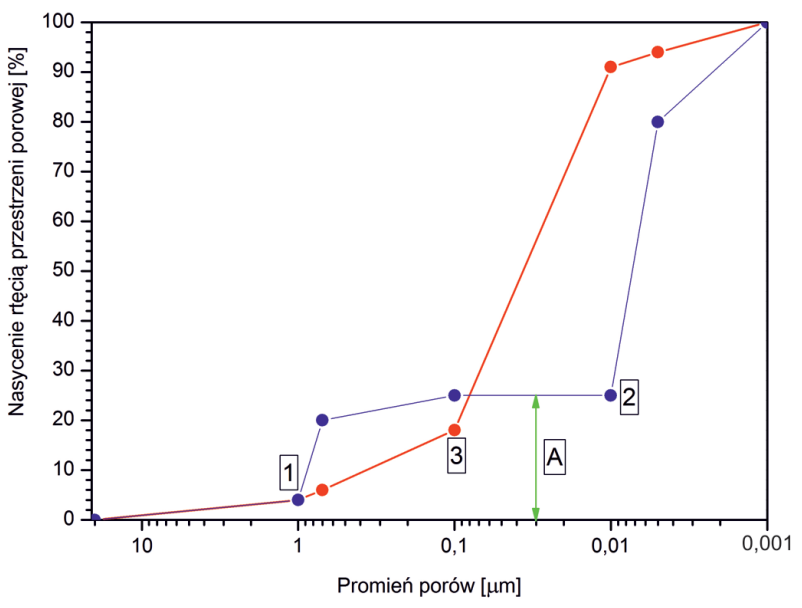

Rys. 3. Typowe przebiegi krzywych kumulacyjnych rozkładu promieni porów: typ I - kolor czerwony (3 - średnica progowa dla I typu krzywej kumulacyjnej), typ II - kolor niebieski (1 - większa średnica progowa, 2 - mniejsza średnica progowa dla II typu krzywej kumulacyjnej), A - objętość przestrzeni porowej związana z większą średnicą progową

Większa wartość średnicy progowej steruje przepływem dla części przestrzeni porowej, którą oznaczono jako A (jest to około $15 \div 25 \%$ porowatości otwartej analizowanej próbki). Właściwości uszczelniające tego typu skał będą zależeć od wartości większej średnicy progowej (mimo faktu, że związana z nią porowatość nie przekracza wartości 2,5\%) [7, 19].

Dla krzywych kumulacyjnych można wyliczyć kapilarne ciśnienie progowe przy pomocy formuły Washbourne'a $[16,18]$, wstawiając kąty kontaktu oraz wartości napięcia międzyfazowego odpowiednie dla danej cieczy złożowej.

\section{Modelowanie zależności wysokości kolumny HC złoża konwencjonalnego od parametrów petrofizycznych formacji uszczelniających}

Określenie parametrów petrofizycznych formacji uszczelniających interwały zbiornikowe węglowodorów umożliwia prowadzenie prac obliczeniowych mających na celu prognozowanie spodziewanych efektów złożowych. Prace takie mogą być realizowane w przypadku słabo rozpoznanych akumulacji węglowodorów lub obiektów perspektywicznych, planowanych do rozpoznania wiertniczego, dla których nie jest znana głębokość zalegania kontaktu wody złożowej i węglowodorów lub też głębokość ta nie jest jednoznacznie określona. Prace obliczeniowe mogą przebiegać na dwa sposoby: 1) z odniesieniem się do obecnych parametrów petrofizycznych formacji uszczelniających i określenia wysokości kolumny węglowodorów, jaką dany interwał ekranujący poziom zbiornikowy jest w stanie utrzymać,

2) z rozpatrzeniem ewolucji właściwości petrofizycznych determinujących jakość uszczelnienia w funkcji czasu geologicznego wraz z postępowaniem procesów pogrą- żania osadów, kompakcji oraz redukcji cech zbiornikowych i filtracyjnych.

W niniejszej pracy obliczenia prowadzone były za pomocą symulatora procesów naftowych PetroMod firmy Schlumberger i uwzględniały, obok wspomnianych powyżej procesów ewolucji parametrów przestrzeni porowej skał, także procesy generacji, ekspulsji, migracji i akumulacji węglowodorów. Pozwoliło to na całościowe rozpatrzenie zarówno procesów odpowiadających za zasilanie poziomu zbiornikowego węglowodorami (przeobrażenie termiczne materii organicznej, generacja, ekspulsja, migracja), jak i warunków do ich zachowania w pułapkach złożowych (powstawanie akumulacji, rozpraszanie węglowodorów) $[8,11,14]$.

W celu przeprowadzenia symulacji ewolucji systemu naftowego, której jednym z elementów jest analiza procesów migracji i akumulacji węglowodorów, konieczne jest zdefiniowanie cech formacji ekranujących poziomy zbiornikowe, 
w tym: modelu opisującego zależność przepuszczalności od porowatości oraz modelu ewolucji wartości ciśnień kapilarnych przebicia (CEP) wraz ze spadkiem porowatości, będących efektem postępowania procesów kompakcji. Wykorzystano wyniki pomiarów laboratoryjnych zrealizowanych w Zakładzie Geologii i Geochemii INiG - PIB w celu zdefiniowania parametrów skały uszczelniającej, które odpowiadają rzeczywistym warunkom dolnopaleozoicznych skał łupkowych z basenu bałtyckiego (rysunek 4 i 5).

Dla powyżej przedstawionego sposobu zdefiniowania cech uszczelniających skał łupkowych dolnego paleozoiku, tworzących nadkład środkowokambryjskiego, piaskowcowego

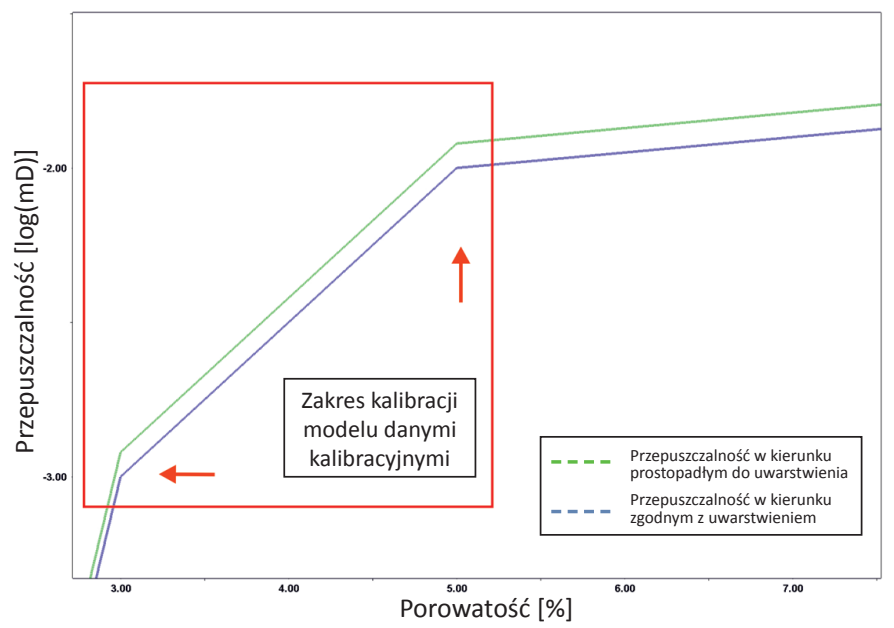

Rys. 4. Wykres zależności przepuszczalności (pionowej i horyzontalnej) od porowatości, skalibrowany dostępnymi wynikami pomiarów laboratoryjnych

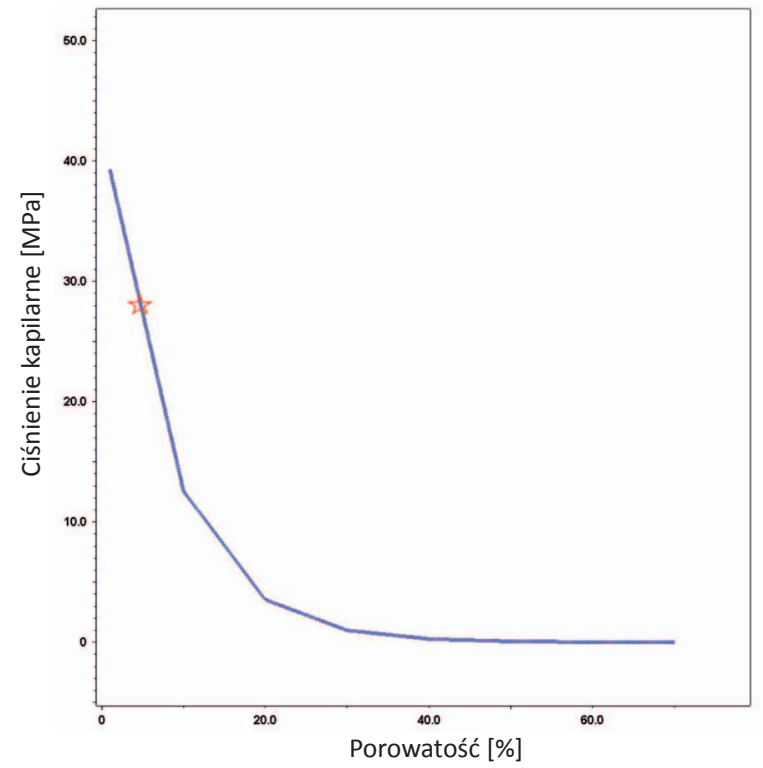

Rys. 5. Zależność pomiędzy porowatością i ciśnieniem kapilarnym przebicia dla rtęci próbek skał łupkowych dolnego paleozoiku z basenu bałtyckiego

poziomu zbiornikowego, przeprowadzono symulację ewolucji systemu naftowego. Pozostałe elementy modelu systemu naftowego, takie jak ewolucja strukturalna i termiczna obszaru badań, przebieg procesów generowania i ekspulsji węglowodorów, zostały wcześniej skalibrowane rzeczywistymi wynikami pomiarów z obszaru badań w ramach innych prac realizowanych w Zakładzie Geologii i Geochemii INiG - PIB [15]. Stopień dopasowania parametrów obliczonych w procesach symulacyjnych do danych pomierzonych można określić jako zadowalający.

\section{Analiza otworowych profili ciśnienia porowego}

Występowanie zróżnicowania w efektywności uszczelnienia poszczególnych formacji zalegających w nadkładzie poziomu zbiornikowego może znajdować swoje odzwierciedlenie w wartościach ciśnienia porowego w profilu basenu sedymentacyjnego $[3,8]$. Mechanizm tego zjawiska przedstawia się następująco: podwyższone, względem generalnego trendu przyrostu z głębokością, ciśnienie porowe jest skutkiem wyższej szczelności formacji zalegającej powyżej. W konsekwencji podczas procesu kompakcji możliwości odpływu wyciskanej z osadów wody złożowej są ograniczone, co prowadzi do obniżenia tempa kompakcji (skutkiem czego wyższe od trendu wartości porowatości), ale też do wzrostu ciśnienia porowego [5, 8, 21, 22].

Wychodząc z powyższych założeń, można oczekiwać, że analiza zmienności wartości ciśnienia porowego (odstępstw od generalnego trendu jego przyrostu z głęboko- ścią) stanowić może kryterium identyfikacji interwałów w profilu geologicznym, które cechują się wyższą efektywnością uszczelnienia.

Analizę ciśnień porowych przeprowadzono przy użyciu oprogramowania Techlog (Schlumberger). Krzywe ciśnień porowych zostały oszacowane metodą Eatona, a następnie poddane kalibracji z wykorzystaniem zbioru danych punktowych - ciśnień porowych szacowanych metodą d-exponent i wyników pomiarów ciśnienia w odwiercie. Przykład jednego $\mathrm{z}$ analizowanych otworowych profili ciśnienia porowego przedstawiono na rysunku 6.

Analiza zinterpretowanych krzywych ciśnień porowych wskazuje na brak przesłanek dla jednoznacznego wydzielania interwałów, w których ciśnienia porowe wskazywałyby na występowanie w ich nadkładzie skał o wyższej efektywności uszczelnienia. 


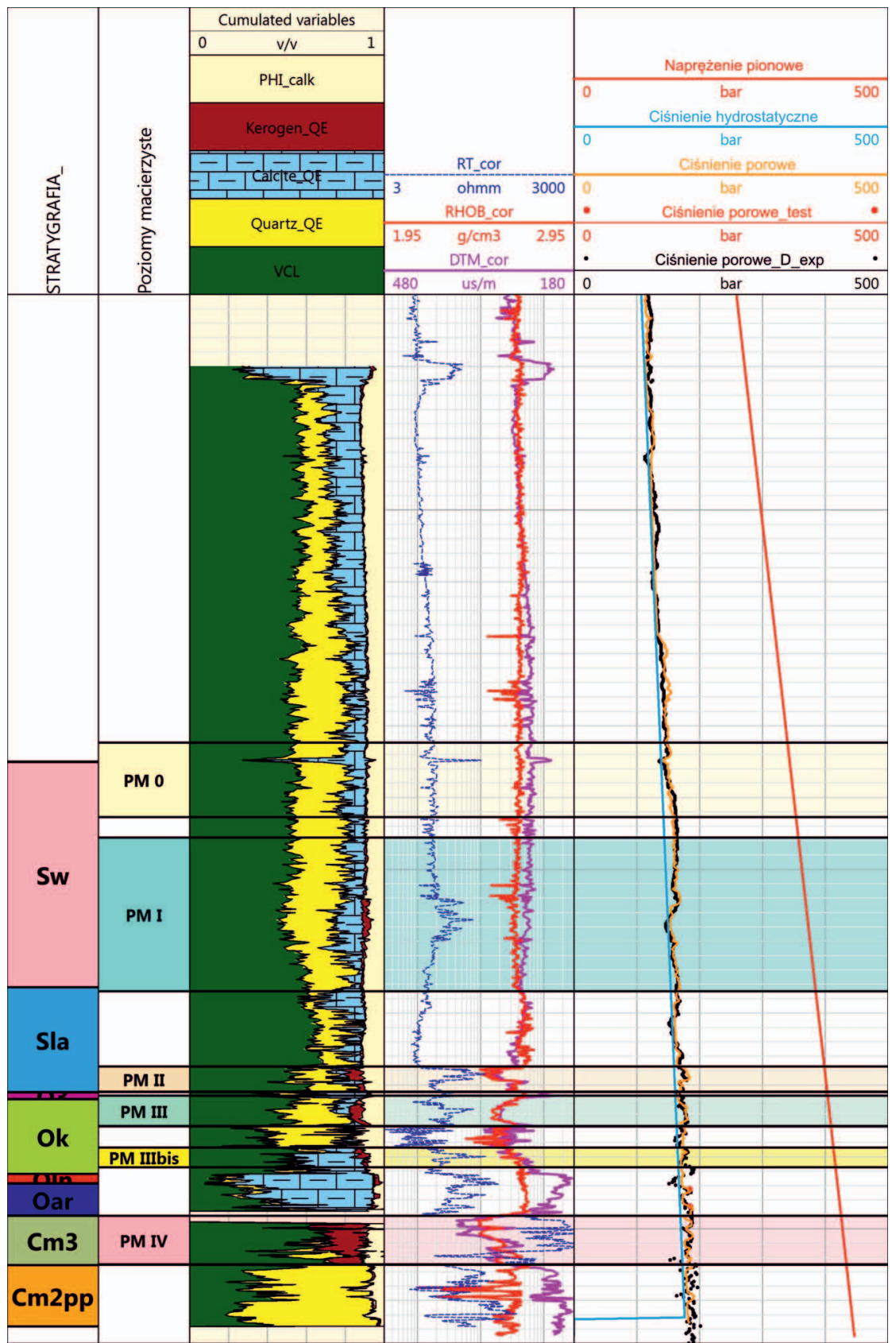

Rys. 6. Ilustracja przedstawiająca obliczone krzywe ciśnienia hydrostatycznego, naprężenia pionowego, ciśnienia porowego dla wybranego odwiertu z obszaru basenu bałtyckiego wraz z naniesionymi punktami kalibracyjnymi (ciśnienie porowe_D_exp szacowane metodą d-exponent i ciśnienie porowe test (pomiar ciśnienia w odwiercie)) oraz wynikami profilowania gęstości (RHOB_cor), oporności elektrycznej (RT_cor) i profilowania akustycznego (DTM_cor)

\section{Wyniki symulacji systemu naftowego}

Analizę wyników symulacji rozpoczęto od prześledzenia czasu napełniania poziomu zbiornikowego węglowodorami, które w wyniku procesu ekspulsji zostały wydalone z poziomów macierzystych (rysunek 7A). Ma to istotne znaczenie z punktu widzenia oceny poprawności zdefiniowanego typu (charakterystyki petrofizycznej) skały uszczelniającej, gdyż pozwoli określić, w jakim przedziale redukcji porowatości i przepuszczalności oraz wzrostu ciśnień kapilarnych przebicia odbywał się proces migracji węglowodorów (rysunek 7B).
Wyniki symulacji wskazują, że napełnianie poziomu zbiornikowego rozpoczęło się około $411 \mathrm{mln}$ lat [Ma] temu, a $398 \mathrm{Ma}$ proces ten nabrał większego tempa. Około 320 Ma nasycenie poziomu zbiornikowego osiągnęło maksimum i od tego czasu biegł proces rozpraszania węglowodorów, trwający do około $250 \mathrm{Ma}$, będący skutkiem wypiętrzania obszaru; od tego czasu poziom nasycenia interwału zbiornikowego utrzymuje się na stałym poziomie. W świetle tych wyników faktyczne znaczenie dla procesów akumulowania węglowodorów będą mieć 

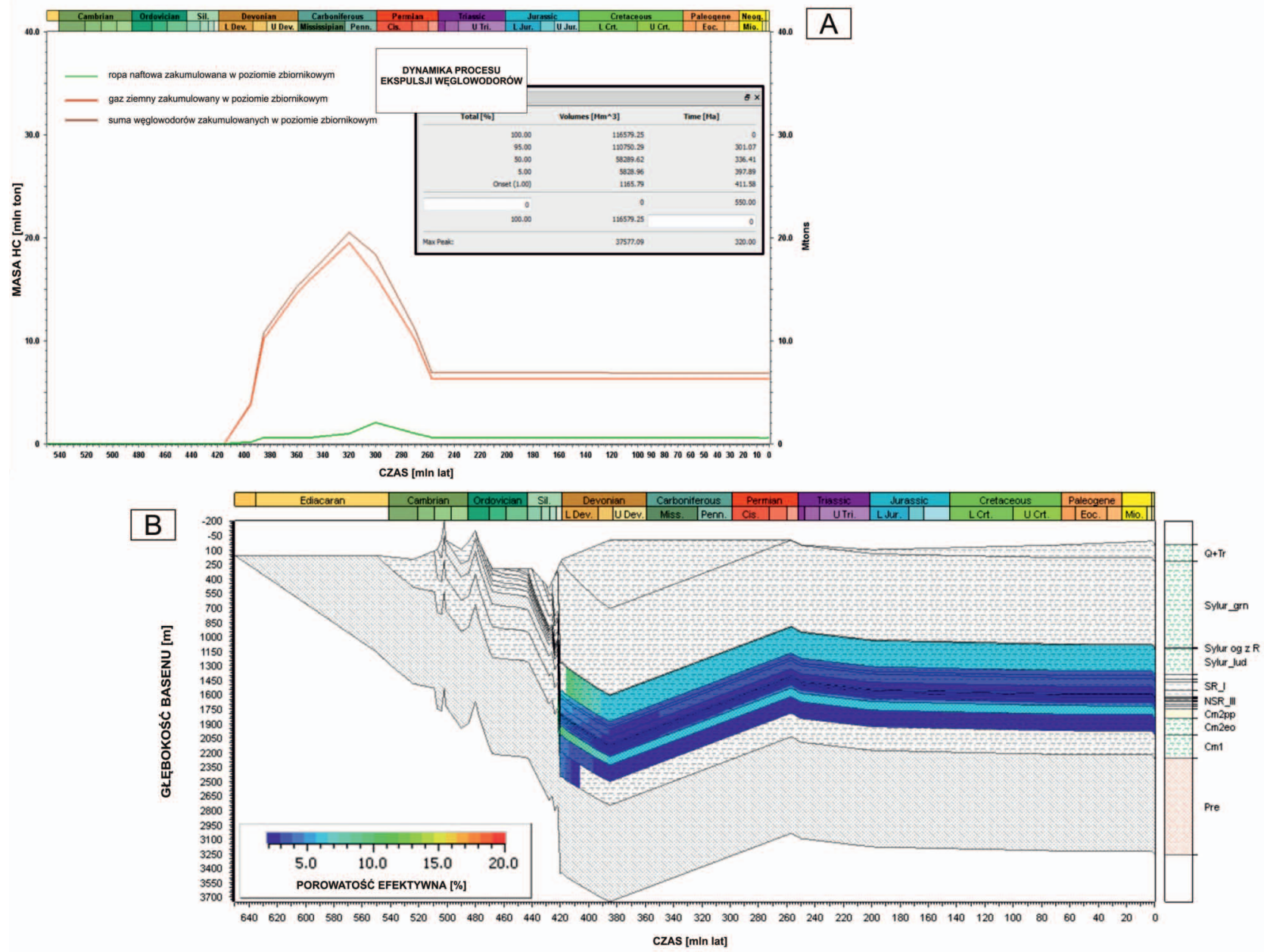

Rys. 7. A) Wykres prezentujący czas napełniania poziomu zbiornikowego węglowodorami (ropą, gazem oraz sumarycznie); w prawym narożniku - tablica prezentująca dynamikę procesu ekspulsji węglowodorów, B) Ewolucja parametru porowatości

efektywnej dolnopaleozoicznego kompleksu skał łupkowych w skali czasu geologicznego na tle ewolucji strukturalnej basenu bałtyckiego

właściwości uszczelniające skał łupkowych ordowiku i syluru w okresie od około 400 Ma do czasu obecnego. W początkowym etapie tego okresu, zgodnie z zakładanym modelem kompakcji, porowatości efektywne łupkowego kompleksu uszczelniającego zawierały się w przedziale (w przybliżeniu) $2 \div 8 \%$ (rysunek 7B). Można zatem stwierdzić, że określona na podstawie danych laboratoryjnych zależność pomiędzy porowatością efektywną i przepuszczalnością (punkty kalibracyjne dla wartości porowatości 3\% i 5\%) obejmowała środek i istotną część przedziału wartości porowatości, przy których odbywały się procesy migracji węglowodorów.

Najistotniejszym kryterium, na którego podstawie można weryfikować poprawność zastosowanej metody oceny efektywności uszczelnienia skał nadkładu poziomu zbiornikowego, jest odtwarzana w modelu głębokość zalegania kontaktu woda-ropa lub woda-gaz czy też wysokość kolumny węglowodorów. Analizowany w ramach niniejszej pracy obiekt złożowy rozpoznany został dotychczas trzema otworami wiertniczymi, w których wyznaczono kilka hipotetycznych (łącznie 5) głębokości zalegania kontaktu woda złożowa-węglowodory na podstawie interpretacji danych geofizyki otworowej w oparciu o znormalizowane zestawienie porowatości neutronowej i gęstościowej. Głębokości te dość istotnie różnią się między sobą (przy średniej głębokości - $1780 \mathrm{~m}$ ), a maksymalny rozrzut głębokości wynosi $42 \mathrm{~m}$, co może być spowodowane dwojakiego rodzaju czynnikami: niejednoznacznością interpretacji anomalii geofizycznych zarejestrowanych w otworze (stąd więcej niż jedna potencjalna głębokość kontaktu w dwóch spośród trzech otworów) $\mathrm{i}$ charakterem wykształcenia skały zbiornikowej w strefie akumulacji HC, w postaci występowania kilku izolowanych względem siebie stref, w których poziomy wody złożowej ustaliły się na innych głębokościach.

Wizualizację analizowanej akumulacji, której zasięg obszarowy oraz wysokość kolumny węglowodorów obliczono metodą modelowania systemów naftowych, stosując symulator PetroMod, przedstawiono na rysunku 8.

Uzyskana w ramach prac symulacyjnych głębokość zalegania kontaktu woda złożowa-węglowodory jest bardzo zbliżona do głębokości, jaką otrzymano, uśredniając kilka hipotetycznych głębokości OWC wyznaczonych na podstawie inter- 


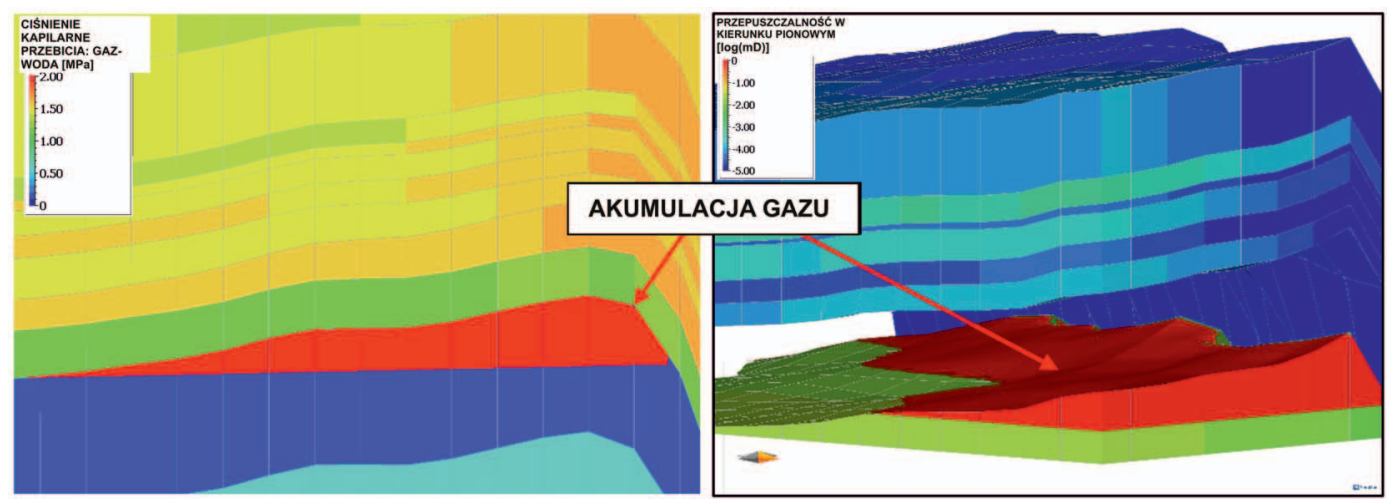

Rys. 8. Wizualizacje przestrzenne analizowanej akumulacji węglowodorów (po lewej: przekrój przez partię złożową na tle dystrybucji wartości ciśnień kapilarnych przebicia dla systemu gaz-woda złożowa; po prawej-w nadkładzie akumulacji węglowodorów zaprezentowano parametr pionowej przepuszczalności kompleksu uszczelniającego)

pretacji danych geofizyki otworowej. Należy podkreślić zupełnie odmienne podejście metodyczne obydwu technik: interpretację zapisów profilowań geofizycznych w otworach, obrazujących obecną sytuację w górotworze, i modelowanie systemów naftowych (w którym uzyskiwany wynik jest konsekwencją szeregu założeń czynionych dla wielu wzajemnie ze sobą powiązanych procesów geologicznych zachodzących na przestrzeni około $500 \mathrm{mln}$ lat). W świetle tych wyników potencjał zastosowanego podejścia metodycznego można ocenić pozytywnie, jednocześnie podkreślając potrzebę kontynuacji testowania metody na innych obiektach złożowych. Potwierdzenie wiarygodności metody na większej liczbie obiektów złożowych pozwoli w przyszłości prowadzić ocenę stanu uszczelnienia i prognozowanie poziomu wypełnienia węglowodorami obiektów perspektywicznych nierozpoznanych wiertniczo.

\section{Podsumowanie}

1. Zintegrowane wykorzystanie wyników pomiarów laboratoryjnych oraz technik modelowania systemów naftowych stanowi obiecującą metodę prognozowania charakteru nasycenia płynami złożowymi nierozwierconych pułapek strukturalnych oraz szacowania stopnia wypełnienia pułapek węglowodorami.

2. Możliwe jest stosowanie dwóch odmiennych wariantów metody, dla różnych uwarunkowań geologiczno-złożowych i poziomów dostępności materiału rdzeniowego:

- dla obszarów, gdzie istnieje dostęp do materiału rdzeniowego, sposób postępowania powinien obejmować zarówno prace laboratoryjne, jak i prace interpretacyjno-obliczeniowe z wykorzystaniem symulatorów systemów naftowych,

- dla obszarów poszukiwawczych, gdzie występują odkryte złoża o wyznaczonej głębokości kontaktu wody złożowej i węglowodorów, możliwe jest przeprowadzenie procesu kalibracji charakterystyki petrofizycznej kompleksu uszczelniającego, w efekcie którego określone zostaną relacje porowatość vs. przepuszczalność i wartości ciśnienia kapilarnego przebicia, pozwalające na odtworzenie wysokości kolumny węglowodorów stwierdzonej w rozpoznanym złożu, a następnie stosowanie tak zdefiniowanych parametrów skał uszczelniających do oceny spodziewanych efektów złożowych dla perspektywicznych obiektów strukturalnych.

3. Przedstawiona w pracy metoda oceny formacji uszczelniających może także w niektórych typach uwarunkowań geologiczno-złożowych stanowić pośredni sposób wnioskowania na temat:

- zasilania poziomu zbiornikowego migrującymi ze skał macierzystych węglowodorami - np. dla słabego stopnia przeobrażenia materii organicznej skał macierzystych, nietypowych dróg migracji węglowodorów lub też remigracji wskutek przebudowy tektonicznej obszaru - co może się objawiać niskim poziomem napełnienia pułapek węglowodorami przy wysokiej szczelności skał nadkładu,

- przepuszczalności stref uskokowych - nieszczelność uskoku(-ów) można podejrzewać, obserwując niski stopień napełnienia HC pułapek domykanych strefami uskokowymi, przy jednoczesnym, potwierdzonym $w$ innych strukturach, wysokim poziomie zasilania migrującymi węglowodorami.

4. Kwestią wymagającą szerszego rozpoznania, na podstawie analizy większej liczby obiektów złożowych, także $\mathrm{w}$ innych basenach sedymentacyjnych, jest poziom niepewności związany z proponowaną metodą oceny właściwości uszczelniających skał. 
Prosimy cytować jako: Nafta-Gaz 2017, nr 10, s. 730-738, DOI: 10.18668/NG.2017.10.02

Artykuł nadesłano do Redakcji 22.12.2016 r. Zatwierdzono do druku 27.06.2017 r.

Artykuł powstał na podstawie pracy statutowej pt.: Wypracowanie metod oceny jakości skał uszczelniajacych poziomy zbiornikowe węglowodorów - praca INiG - PIB na zlecenie MNiSW; nr zlecenia: 111/SG/2016, nr archiwalny: DK-4100-167/16.

\section{Literatura}

[1] Anovitz L.M., Cole D.R.: Characterization and Analysis of Porosity and Pore Structures. Reviews in Mineralogy \& Geochemistry 2015, vol. 80, nr 1, s. 61-164.

[2] Beaumont E.A., Foster N.H. (eds.): Treatise of Petroleum Geology: Exploring for Oil and Gas Traps. AAPG 1999, s. $25-27$.

[3] Bjorlykke K.: Petroleum Geoscience. From Sedimentary Environments to Rock Physics. Springer 2010.

[4] Bogno T., Graue A.: Impacts of Capillary Pressure Imbibition Curves on the Simulation of Waterfloods in High Capillary Moderately-Water-Wet Chalk. $6^{\text {th }}$ Nordic Symposium on Petrophysics, Trondheim, Norway, 15-16.05.2001.

[5] Bourgoyne A.T., Millheim K.K., Chenevert M.E., Young F.S.: Applied Drilling Engineering. Society of Petroleum Engineers, Richardson 1986.

[6] Cathles L.M.: Capillary Seals as a Cause of Pressure Compartmentation in Sedimentary Basins. GCSSEPM Foundation $21^{\text {st }}$ Annual Research Conference Petroleum Systems of Deep-Water Basins, 2-5.12.2001.

[7] Civan F., Rai Ch.S., Sondergeld C.H.: Shale-Gas Permeability and Diffusivity Inferred by Improved Formulation of Relevant Retention and Transport Mechanisms. Transp. Porous Med. 2011, vol. 86, nr 3, s. 925-944.

[8] Hantschel T., Kauerauf A.: Fundamentals of Basin and Petroleum Systems Modeling. Springer 2009.

[9] Heller R., Vermylen J., Zoback M.: Experimental investigation of matrix permeability of gas shales. AAPG Bull. 2014, vol. 98, nr 5, s. 975-993.

[10] Ingram G.M., Urai J.L., Naylor M.A.: Sealing processes and top seal assessment. NPF Special Publication 7, s. 165-174, Elsevier, Singapore 1997.

[11] Schlumberger: PetroMod 2015.1 - User's Guide.

[12] Schlumberger: PetroMod Advance Topics. Workflow/Solutions Training, 2015.

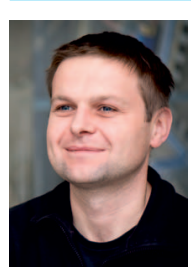

Dr inż. Krzysztof SOWIŻDŻAŁ

Adiunkt w Zakładzie Geologii i Geochemii

Instytut Nafty i Gazu - Państwowy Instytut Badawczy

ul. Lubicz 25 A

31-503 Kraków

E-mail:krzysztof.sowizdzal@inig.pl

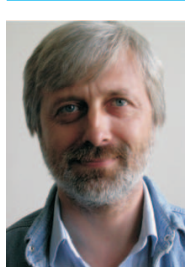

Dr inż. Grzegorz LEŚNIAK

Adiunkt; kierownik Zakładu Geologii i Geochemii. Instytut Nafty i Gazu - Państwowy Instytut Badawczy ul. Lubicz 25 A

31-503 Kraków

E-mail: grzegorz.lesniak@inig.pl
[13] Schlumberger: PetroMod Calibration Workflows for Petroleum Systems Models. Training and Exercise Guide (Confidential), 2014.

[14] Schlumberger: PetroMod Petroleum Systems Modeling for Shale Plays. Training Guide (Confidential), 2015.

[15] Sowiżdżał K., Słoczyński T.: Dynamiczne modelowanie systemów naftowych $4 D$ w wybranych strefach basenu baltyckiego w rozpoznawaniu złóż węglowodorów $w$ formacjach tupkowych. Nafta-Gaz 2016, nr 12, s. 1018-1027, DOI: 10.18668/ NG.2016.12.02.

[16] Such P: Wykorzystanie porometrii rtęciowej w analizie struktury przestrzeni porowej skat zbiornikowych. Prace IGNiG 2002, nr 113, Kraków.

[17] Such P., Dudek L., Mroczkowska-Szerszeń M., Cicha-Szot R.: The influence of reservoir conditions on filtration parameters of shale rocks. Nafta-Gaz 2015, nr 11, s. 827-833, DOI: 10.18668/NG2015.11.03.

[18] Tiab D., Donaldson E.C.: Petrophysics. Gulf Publishing Comp., Houston, Texas 1996.

[19] Wang S., Javadpour F., Feng Q.: Confinement Correction to Mercury Intrusion Capillary Pressure of Shale Rocks. Scientific Report 2016, vol. 6, article 20160, DOI: 10.1038/ srep20160.

[20] Wardlaw N.C., Taylor R.P.: Mercury Capillary Pressure Curves and the Interpretation of Pore Structure and Capillary Behaviour in Reservoir Rocks. Bull. of Canadian Petr. Geol. 1976, vol. 24, nr 2, s. 225-262.

[21] Zhang J.: Effective stress, porosity, velocity and abnormal pore pressure prediction accounting for compaction disequilibrium and unloading. Mar. Pet. Geol. 2013, vol. 45, nr 8, s. 2-11.

[22] Zhang J.: Pore pressure prediction from well logs: methods, modifications and new approaches. Earth-Science Reviews 2011, vol. 108, nr 1-2, s. 50-63.

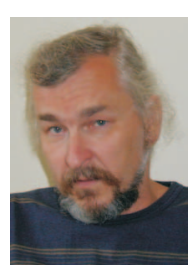

Prof. nzw. dr hab. Piotr SUCH

Zastępca Dyrektora ds. Poszukiwania Złóż Węglowodorów.

Instytut Nafty i Gazu - Państwowy Instytut Badawczy ul. Lubicz 25 A

31-503 Kraków

E-mail:piotr.such@inig.pl

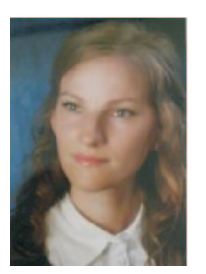

Dr inż. Małgorzata SŁOTA-VALIM

Asystent w Zakładzie Geologii i Geochemii, Laboratorium Petrofizyki.

Instytut Nafty i Gazu - Państwowy Instytut Badawczy ul. Lubicz 25 A

31-503 Kraków

E-mail: slota@inig.pl 